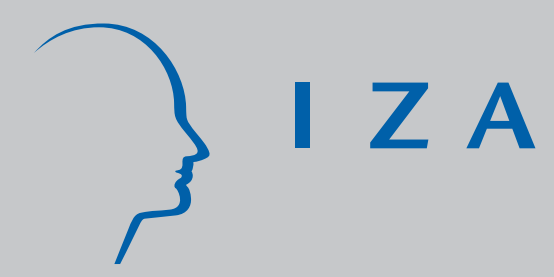

IZA DP No. 3888

Do Small Businesses Create More J obs? New Evidence for the United States from the National Establishment Time Series

David Neumark

Brandon Wall

J unfu Zhang

December 2008 


\title{
Do Small Businesses Create More Jobs? New Evidence for the United States from the National Establishment Time Series
}

\author{
David Neumark \\ University of California, Irvine, \\ Public Policy Institute of California, \\ NBER and IZA \\ Brandon Wall \\ Stanford University \\ Junfu Zhang \\ Clark University and IZA \\ Discussion Paper No. 3888 \\ December 2008 \\ IZA \\ P.O. Box 7240 \\ 53072 Bonn \\ Germany \\ Phone: +49-228-3894-0 \\ Fax: +49-228-3894-180 \\ E-mail: iza@iza.org
}

Any opinions expressed here are those of the author(s) and not those of IZA. Research published in this series may include views on policy, but the institute itself takes no institutional policy positions.

The Institute for the Study of Labor (IZA) in Bonn is a local and virtual international research center and a place of communication between science, politics and business. IZA is an independent nonprofit organization supported by Deutsche Post World Net. The center is associated with the University of Bonn and offers a stimulating research environment through its international network, workshops and conferences, data service, project support, research visits and doctoral program. IZA engages in (i) original and internationally competitive research in all fields of labor economics, (ii) development of policy concepts, and (iii) dissemination of research results and concepts to the interested public.

IZA Discussion Papers often represent preliminary work and are circulated to encourage discussion. Citation of such a paper should account for its provisional character. A revised version may be available directly from the author. 


\title{
ABSTRACT
}

\section{Do Small Businesses Create More Jobs? New Evidence for the United States from the National Establishment Time Series ${ }^{\star}$}

\begin{abstract}
We use a new database, the National Establishment Time Series (NETS), to revisit the debate about the role of small businesses in job creation. Birch (e.g., 1987) argued that small firms are the most important source of job creation in the U.S. economy. But Davis et al. (1996a) argued that this conclusion was flawed, and based on improved methods and using data for the manufacturing sector, they concluded that there was no relationship between establishment size and net job creation. Using the NETS data, we examine evidence for the overall economy, as well as for different sectors. The results indicate that small firms and small establishments create more jobs, on net, although the difference is much smaller than what is suggested by Birch's methods. Moreover, in the recent period we study, a negative relationship between establishment size and job creation holds for both the manufacturing and services sectors.
\end{abstract}

JEL Classification: J20, L25, L53

Keywords: $\quad$ job creation, job destruction, small businesses

Corresponding author:

David Neumark

Department of Economics

3151 Social Science Plaza

University of California, Irvine

Irvine, CA 92697

USA

E-mail: dneumark@uci.edu

\footnotetext{
*Neumark's and Wall's research was supported by the Kauffman Foundation, and our work with the national version of the National Establishment Time Series was made possible by a grant from the David A. Coulter Family Foundation to the Public Policy Institute of California. We are grateful for helpful comments received from the editor and an anonymous reviewer. All views expressed are our own, and do not represent those of the Kauffman Foundation, the Public Policy Institute of California, or the David A. Coulter Family Foundation.
} 


\section{Introduction}

Ever since the provocative work of David Birch (1979, 1981, and 1987), researchers have paid considerable attention to the role of small businesses in job creation. ${ }^{1}$ The central thesis of Birch's research was that small firms are the most important source of job creation in the U.S. economy. ${ }^{2}$ Birch (1979, 1981) provided the first evidence in support of the argument that small businesses are the primary engines of job growth, claiming that $66 \%$ of all net new jobs in the United States during 1969-1976 were created by firms with 20 or fewer employees and $81.5 \%$ were created by firms with 100 or fewer employees. Later, Birch (1987) argued that during the period 1981-1985, firms with fewer than 20 employees accounted for $82 \%$ of employment growth via expansion and contraction of existing firms (Figure 1-3, p. 14), and 88.1\% of overall employment growth (Figure 1-5, p. 16).

Birch’s argument about the important role of small business in job creation fit perfectly with the U.S. government's long tradition of supporting small businesses. As early as 1953, the U.S. Congress passed the Small Business Act with the intention to aid, counsel, assist, and protect the interests of small businesses. Under this act, the federal government established the Small Business Administration to ensure that a fair proportion of government contracts went to small businesses. The Small Business Administration also makes direct loans and guarantees bank loans to small businesses, based on the perspective that assisting small businesses is important to preserve free competitive enterprise and to maintain and strengthen the U.S. economy. ${ }^{3}$ Birch’s findings fed into this thinking and quickly became conventional wisdom. ${ }^{4}$ Since then, his findings have often been cited as justification for favorable government regulations, tax incentives, and support programs for small businesses. ${ }^{5}$ Birch’s work

\footnotetext{
${ }^{1}$ See, for example, Baldwin and Picot (1995), Barnes and Haskel (2002), Broersma and Gautier (1997), Davis et al. (1996a, 1996b), Hohti (2000), and Wagner (1995).

${ }^{2}$ There is a parallel, yet largely separate, industrial organization literature that asks how employment growth varies by firm size. Much of this literature responds to what is known as "Gibrat's Law," which states that firm growth rates are independent of size (Gibrat, 1931). As a behavioral conjecture proposed to explain the observed firm size distribution, Gibrat's law has generated a large amount of research testing its validity; see the review in Sutton (1997).

${ }^{3}$ See http://www.sba.gov/aboutsba/index.html (viewed October 31, 2007).

${ }^{4}$ See Davis et al. (1996b) for a long list of quotes from the media and political speeches that recite this conventional wisdom.

${ }^{5}$ A series of legislative actions has continued the tradition of helping small businesses since Birch's work, including, for example: the Small Business Economic Policy Act of 1980; the Small Business Innovation Development Act of
} 
appears to have had a lasting effect on U.S. policy. For example, the U.S. Small Business Administration has an Office of Advocacy (for small businesses) that still trumpets Birch’s findings in trying to help small businesses with regard to regulatory constraints, taxation, etc. ${ }^{6}$

Birch’s work also attracted considerable criticism. Brown et al. (1990) emphasize that the number of jobs created by an employer is not the only thing that matters. Spurred by Birch’s findings and the attention they attracted, Brown et al. compare jobs created by small firms with those created by large firms. They argue that jobs created by small firms are less desirable because they tend to exist for a shorter period of time, pay lower wages, and have less generous fringe benefits in terms of health insurance, vacation, and pension plans. In addition, they argue that small firms tend to have poorer working conditions, provide less job training, and have higher job turnover rates. ${ }^{7}$ Based on these findings, they recommend that policymakers should be cautious about encouraging policies to help small firms. Although the argument of Brown et al. is an important one, it is not the focus of our paper. Second, focusing more specifically on the job creation debate, Davis et al. (1996a) criticize the calculation used by Birch, which divides firms into size classes and then examines the variation in job growth across size classes. In particular, they argue that these calculations are subject to a "regression fallacy" that leads to upward bias in the estimated contribution of small firms to job growth. When they use a calculation that, they argue, is not prone to this bias, with data on the manufacturing sector from the

\footnotetext{
1982; the Small Business Competitiveness Demonstration Program Act of 1988; the Small Business Technology Transfer Act of 1992; the National Small Business Act of 1996; the Small Business Job Protection Act of 1996; the Small Business Regulatory Enforcement Fairness Act of 1996; the Small Business Reauthorization Act of 1997; the Small Business Franchise Act of 1999; the Small Business Procurement Competition Act of 2001; the Small Business Paperwork Relief Act of 2002; and the Small Business Health Fairness Act of 2005. In determining eligibility for most of these programs, the Small Business Administration specifies size standards on an industry-byindustry basis, most commonly based on number of employees, but sometimes based instead on annual receipts. The employee size thresholds range from 100 for wholesale trade to 1,500 for industries such as petroleum refineries, air transportation, and telecommunications. (See http://www.sba.gov/idc/groups/public/documents/sba_homepage/serv_sstd_tablepdf.pdf, viewed October 31, 2007, for a complete list of the size standards.)

${ }^{6}$ See http://www.sba.gov/advo/25ann.html and http://www.sba.gov/advo/mission.html (viewed October 7, 2007).

${ }^{7}$ In their work, their analysis of job creation looks at firms, while their analyses of other issues, such as wage premiums and fringe benefits, look at both firms and establishments.
} 
Longitudinal Research Database (LRD) covering the period 1973-1988, they conclude that employment growth appears to have "no systematic relationship to average plant size” (p. 68). ${ }^{8}$

In this paper, we use a new database, the National Establishment Time Series (NETS), which was constructed using the most recent waves of the Dun and Bradstreet (D\&B) data. The availability of this new database provides a valuable opportunity to revisit the Birch thesis as well as the conclusions drawn by Davis et al. Given that Davis et al.'s results come solely from the manufacturing sector, it is important to ask whether their conclusions apply to the overall economy, and to other sectors of the economy, which we are able to do using the NETS data. ${ }^{9}$ Also, the answer to the questions addressed by this research may depend on the period studied. In particular, innovative start-ups appeared to have played an important role in the Internet revolution and the boom of the "new economy" in the late 1990s (Audretsch and Thurik, 2001), raising the possibility that in this period (and extending beyond the manufacturing sector) new (and thus mostly small) firms contributed more to employment growth. ${ }^{10}$

\section{Previous Research}

Birch’s work prompted numerous researchers to consider his methods and to test his hypothesis in different countries. ${ }^{11}$ Focusing first on methods, Davis et al. (1996a) criticize the statistical analysis leading to Birch's conclusions, pointing out that when businesses are classified by size for a given base year, two types of firms will "accidentally" fall into a smaller size category: firms that are not small but have just experienced a transitory negative shock to their employment and appear to be small for the moment; and firms that are not small but are mistakenly classified as small due to random measurement

\footnotetext{
${ }^{8}$ Davis et al. (1996a) report results based on both plant and firm size (e.g., Table 4.1, p. 61). However, the results they used to refute Birch are based on plant size (Table 4.2, p. 69).

${ }^{9}$ Indeed, there are reasons to believe that growth patterns in the manufacturing sector may not apply to the rest of the economy. As Klepper and Graddy (1990) observed, the number of firms in an industry will grow first, then decline sharply, and level off eventually. Thus, new and mature industries tend to show different industrial structures and growth patterns. For example, one may find a large number of new (and thus small) firms in a new industry, which grow fast and contribute a large share of employment growth. On the contrary, a mature industry may be shrinking and usually it is the smaller firms that exit first and thus constitute a large share of job loss. One of the most prominent features of the U.S. manufacturing sector is that its total employment (relative to the U.S. total) has been continuously declining since 1950 (Sachs and Shatz, 1994).

${ }^{10}$ Although young firms and small firms overlap a great deal, they are conceptually distinct groups. Most research, following the tradition established by Birch, focuses on the dichotomy of small and large firms. See Neumark et al. (2006) for some discussion of the contribution to job growth by young and old firms.

${ }^{11}$ Much of the latter research appeared in Small Business Economics, the founding of which was partly inspired by Birch's work (Acs and Audretsch, 1989).
} 
errors. If such transitory shocks or random measurement errors are not highly serially correlated, both types of "small” firms will "grow" fast over the next year only because of regression to the mean. A reverse argument can be made for large firms. That is, some large firms are categorized as large only because of positive transitory shocks and random measurement errors. These firms tend to experience negative growth if the transitory shocks or the measurement errors are not strongly serially correlated, leading to a downward bias in the estimated growth rate of large firms. ${ }^{12,13}$

To avoid this statistical pitfall, Davis et al. propose computing job creation and destruction rates from the base period $t$ to period $t+1$ relative to the average employment level in these two periods. ${ }^{14}$ Davis et al. argue that the regression fallacy fully explains the relationship between establishment size and job growth. As noted in the Introduction, using the average instead of a base-year size measure, they find no systematic relationship between manufacturing plant size and employment growth. ${ }^{15}$ They also suggest that the measurement error in the D\&B data used by Birch is more serious than in their LRD data,

\footnotetext{
${ }^{12}$ In earlier work, Leonard (1986) also argues that the larger role of small businesses in job creation is an artifact resulting from regression to the mean. Leonard (1987) reports some direct evidence consistent with regression to the mean in establishment size (Table 6.7), and suggests that it is attributable to real dynamics, rather than measurement error (p. 154).

${ }^{13}$ Davis et al. (1996a) and Kirchhoff and Green (1998) point out that many studies prior to Birch (1979), which did not use longitudinal data, could have either overstated or understated job growth due to smaller firms or larger firms, depending on whether firms were on average shrinking or growing. Lacking establishment-level data, these preBirch studies typically calculated the number of new jobs in each size category as the difference between the number of jobs in the size category this year and the number of jobs in the same size category in the previous year. This procedure wrongly assumes that firms do not move between size categories. Thus, for example, in periods in which firms are on average growing, this results in overstatement of job growth in large firms because jobs created when firms grow into a larger size class are mistakenly interpreted as job creation by firms in that size class.

${ }^{14}$ Somewhat confusingly, they refer to this as the "current" establishment size measure. Davis et al. (1996a, 1996b) also define a historical average size as a weighted average of employment over all years of an establishment's existence in the sample period, using employment as the weight. They consider this as a measure of the business establishment's "intended scale of operations." By this definition, a business is small only if it is intended to be small and thus stays small for many years. From this perspective, employment fluctuations at the business establishment level are considered mostly random, as a result of changes in demand or other market conditions. Carree and Klomp (1996) cast doubt on the usefulness of this concept of long-run firm size. First, facing constant environmental changes, a firm should and will continuously adjust its optimal size. This reality is in conflict with the concept of long-run firm size that is assumed to be stable over a long period of time. Second, for young firms that just entered the market, it is simply impossible to know their intended long-run size. We therefore do not use this latter measure. Our “average” measure corresponds to Davis et al.’s “current” measure, as "average” seems a more appropriate label.

${ }^{15}$ Davis et al. also extend their criticism to similar calculations typically included in the annual Small Business Administration Report to the President (in the mid- to late-1980s).
} 
and thus that the regression fallacy bias is even more severe in Birch’s results (Davis et al., 1996a, p. $70) .^{16}$

In response to Davis et al.’s (1996a) criticism of Birch’s findings, Davidsson et al. (1998) consider whether the regression fallacy can account for the apparent important role of small firms in job creation, by attempting to estimate the bias from the regression to the mean that underlies the regression fallacy. Based on evidence from Swedish data, they suggest that the regression fallacy accounts for little distortion in the relationship between firm size and net job growth. Indeed, in the broader research literature on firm (or establishment) size and job creation prompted by Birch’s work, which covers many countries, analyses that use Davis et al.’s (1996a) method to avoid the regression fallacy more often than not confirm the finding that small establishments or firms contribute more to job growth. For example, Kirchhoff and Phillips (1988) examine the contribution of small and large firms to U.S. job growth. They find that firms with fewer than 100 employees are the major sources of net new job creation. In contrast, firms with more than 1,000 employees provided only 13\% of all new jobs despite their $37 \%$ employment share (in 1985). Using Canadian data on the manufacturing sector, Baldwin and Picot (1995) find that net job creation by small manufacturing establishments is greater than that of large establishments. Broersma and Gautier (1997), using firm-level data for the Netherlands, find that small firms contribute more to net job creation than large ones. For the United Kingdom, Barnes and Haskel (2002) find that small establishments contribute more to net job creation. Voulgaris et al. (2005) also find that small firms create more jobs on net, using data from Greece. On the other hand, Hohti (2000), studying data for Finland, reaches a conclusion more in line with Davis et al. (1996a) - that there is no clear relationship between establishment size and net job creation. ${ }^{17}$

\footnotetext{
${ }^{16}$ In addition to avoiding the regression fallacy, the average size also is widely used because it captures job creation and destruction symmetrically (e.g., Pivetz et al., 2001, pp. 14-15). For example, suppose a firm's number of employees is 1, 2, and 1 in three consecutive years. If we use base-year employment as the denominator to calculate growth rate, this firm has experienced $100 \%$ job growth followed by $50 \%$ job decline. Alternatively, if we use twoyear average employment as the denominator, this firm has $67 \%$ job growth $(=1 / 1.5)$ followed by $67 \%$ job decline $(=-1 / 1.5)$.

${ }^{17}$ Some research has also documented that, whereas small firms create a large share of new jobs, they are also responsible for a large share of job loss. For example, using data on manufacturing establishments from Germany, Wagner (1995) finds that although net job creation rates are not systematically related to establishment size, gross
} 
One limitation of the existing literature is that much of it focuses on the manufacturing sector. ${ }^{18}$ However, findings from that sector do not necessarily apply to other industries; ample empirical evidence shows that depending on the relative importance of entry cost, scale economies, industry growth, and capital intensity, the relationship between survival rate and firm size varies a great deal from one industry to another. ${ }^{19}$ Because of this difference in survival, it is natural that small firms may be found to grow faster than larger ones in one industry but not in another when one examines surviving as well as exiting firms. Davidsson et al. (1998) - echoing concerns raised by other researchers - questioned whether one should draw general implications regarding the behavior of small establishments or firms in job creation from the information on plant-level data from the declining manufacturing sector in the United States used by Davis et al. (1996a, 1996b). Using data from the Dutch services sector, Audretsch et al. (2004) show that firm growth in services is largely independent of firm size, in contrast to evidence from manufacturing. Lotti (2007) compares the patterns of firm entry, growth, and survival in manufacturing and services. He finds that the patterns in the services sector are qualitatively similar to the stylized facts from the manufacturing sector, although there are some differences quantitatively. For example, the positive effect of firm size on firm survival is larger in the services sector.

\section{The National Establishment Time Series Database}

The database used in this study, the National Establishment Time Series (NETS), is a relatively new longitudinal file created by Walls \& Associates using D\&B data (Walls \& Associates, 2003). In this paper, we report results based on the full national NETS file, which covers all business establishments in the United States beginning in 1989, including their parent headquarters. ${ }^{20}$ The NETS database does not contain a rich set of information about each establishment, but it does include the business name, a unique

job creation and destruction rates tend to be higher the smaller the establishment. Broersma and Gautier (1997), Hohti (2000), and Barnes and Haskel (2002) also find that small firms have both higher job creation and higher job destruction rates than large ones. Similar results are reported by Gallagher et al. (1991) for the United Kingdom, for the period 1985-1987, with small firms contributing $48 \%$ of job creation but also $43 \%$ of job destruction, although they constituted only $21 \%$ of all employment in 1985 . For this period, there is some evidence that small firms create more jobs on net, although the relationship is not very clear (Table IX).

${ }^{18}$ See also Dunne et al. (1989), Evans (1987), and Hall (1987), all of which use data from the manufacturing sector; Dunne et al. study establishments, and the other two papers study firms.

${ }^{19}$ See the long list of references cited in Audretsch et al. (2004).

${ }^{20}$ Purchasing the NETS database for the entire United States is very expensive, costing \$200,000 for a two-year license. 
D\&B establishment identifier (the DUNS number), the establishment location, an SIC code in each year (which we have converted to a NAICS code), the type of location (single location, headquarters, branch) in each year, the identifier of the firm's headquarters, and employment (as well as sales, which we do not use) in each year. Although the data extend back to 1989, we regard the data prior to 1992 as less reliable, because only beginning in 1992 was D\&B able to purchase information on business units (from the Yellow Pages) from the regional Bells; we therefore use data beginning in 1992, and extending through $2004 .^{21}$

The unit of observation in the NETS is a business establishment, which is a business or industrial unit at a single physical location that produces or distributes goods or provides services - for example, a single store or factory. Of course many firms own or control more than one establishment, and those establishments may be located in different geographic areas and may be engaged in different industries. The NETS data indicate whether an establishment is a stand-alone firm or a branch of a multiestablishment firm, and in the latter case establishments of the same firm can be linked via the identifier for the firm's headquarters. We use the word "business" to refer generically to firms or establishments, reserving the word "firm” to refer to what may be collections of many establishments with a common owner.

One highly desirable feature of the NETS database is that it covers essentially all firms and establishments. This reflects the fact that it is designed to capture the universe rather than a sample of establishments. Over the sample period of 1992-2004 that we study, the database includes information each year on an average of about 13.1 million firms and 14.7 million establishments. In total, more than 157 million firm-year observations and 177 million establishment-year observations are covered in the NETS database.

The data construction effort - including both the cross-sectional files and the longitudinal linking that tracks establishments over time - is a massive and complicated one. Details are provided in Neumark

\footnotetext{
${ }^{21}$ We have previously used the NETS data for California to study business relocation (Neumark et al., 2007) and the contribution of new firms to employment growth (Neumark et al., 2006). Other work uses the NETS data to study changes in the geographic scope of firms' operations (Kolko and Neumark, 2008) and agglomeration economies in the high-tech sector (Wallace and Walls, 2004).
} 
et al. (2007). As previously noted, the earlier D\&B data (from thirty years ago) that were used in Birch’s work came in for considerable criticism. In particular, Davis et al. (1996a, 1996b) assert that these data were not particularly suitable for studying job creation-destruction dynamics for two reasons. First, early D\&B data gave a much higher total employment level than alternative data sources such as those from Census or the Bureau of Labor Statistics (BLS). Second, the early D\&B data did a poor job in terms of capturing new businesses, as documented in previous research that Davis et al. cite (and discussed further in Neumark et al., 2007). However, information technology has improved dramatically during the decades since then, and data sources have changed. Consequently the quality of the D\&B data may have improved substantially. For these reasons, we have undertaken a good deal of investigation to document and examine the quality of the NETS data, in order to assess their reliability and their potential limitations, and how these limitations might affect results of various analyses. ${ }^{22}$ We do not repeat the details here, except to focus on those issues highlighted in the earlier work that are most relevant to the analysis in this paper.

We assessed the reliability of the NETS data for measuring employment levels and changes by comparing the NETS with data from the Quarterly Census of Employment and Wages (QCEW), the Current Employment Statistics (payroll) survey (CES), and the Size of Business data (SOB). ${ }^{23}$ In these latter data sources we cannot identify establishments, but we can look at employment by industry, county, and size category. We find that the NETS does report higher aggregate employment levels, but that this appears to be mainly because it covers more very small businesses than alternative databases do. On the other hand, there is a fair amount of rounding of reported employment as well as imputation of missing data. As a result, the NETS data seem to show firm/establishment employment changes less frequently

\footnotetext{
${ }^{22}$ See Neumark et al. (2007) as well as Kolko and Neumark (2008).

${ }^{23}$ The exact meaning of employment in the NETS data is somewhat different from what is used by the BLS. The BLS usually defines a firm's (or establishment's) employment as the number of employees on payroll on a particular date; the QCEW, CES, and SOB all use this definition. In contrast, D\&B continuously collects employment information throughout the year. The interviewer/online questionnaire asks a broad question: "How many persons are employed at your establishment?" No particular date is specified in the question and it does not distinguish between full-time and part-time employees. D\&B's employment number also includes the owner of the business, whereas these other sources capture employees only. The annual NETS Database is constructed using January snapshots of the D\&B data - i.e., the data as of January of each year.
} 
than we would expect. As shown below, some of our analysis addresses possible biases from rounding and imputation of employment. ${ }^{24}$

It is important to track establishment births accurately in studying employment growth at small establishments. Two approaches were used to check the accuracy with which the NETS data capture new establishments: comparisons to new establishments identified from phonebooks in consecutive years, coupled with information elicited from these establishments on their actual start dates; and comparisons of the NETS data to a convenient listing of California biotech companies in the BioAbility database of U.S. biotech companies. ${ }^{25}$ In both cases, Neumark et al. (2007) found that the NETS data identified establishment openings and their start dates very accurately.

Tracking births (and deaths) also requires distinguishing these events from relocations. For example, if a business first appears at an address in year $t$, it is important to know whether it is a new business or one that moved from elsewhere; in the latter case, this should not be considered a birth. Similarly, if a business moves to a new location, its absence at the old location should not be considered a death. By comparing relocations in the NETS with those identified in Lexis-Nexis searches, we were able to confirm that the NETS captures relocations quite well.

Finally, in this paper we focus on analysis at the firm level. This raises the question of how well the NETS links existing establishments and new establishments (births) to their parent firms. Assessing this requires another data source on the establishments belonging to a firm, including births of new establishments. Through some efforts, we were able to obtain such data for three large companies - a retail merchandiser, a manufacturer of computer equipment, and a restaurant chain. Overall, the tracking of firms’ establishments works quite well, although there are sometimes establishments from the alternative data sources that do not appear in the NETS, or vice versa. These "matching” errors appear to

\footnotetext{
${ }^{24}$ We doubt that any of the databases used in empirical research in this field are free of these rounding and imputation problems. Unfortunately, researchers have little information about the nature or the consequences of measurement error created by rounding and imputation.

${ }^{25}$ This is a database of more than 2,000 U.S. biotech companies maintained by BioAbility, a biotech consulting firm. See http://www.bioability.com/us_biotech_companies.htm (viewed September 14, 2005).
} 
arise largely in the most recent years of the data set because the NETS sometimes detects new establishments with a delay. ${ }^{26}$

Overall, we find that the NETS database, like all others, is not without its flaws, and has both advantages and limitations. Its complete coverage of the whole economy annually is an advantage that we value most for our study here. ${ }^{27}$ To answer the question whether small businesses create more jobs, we think it crucial to examine all sectors of the economy instead of just the manufacturing sector that most previous research has focused on. Earlier D\&B data were criticized for reporting higher aggregate employment levels and capturing the births of businesses poorly. With the NETS database, which was constructed using more recent $\mathrm{D} \& \mathrm{~B}$ data, we find that the former is not a serious concern and the latter is largely invalid.

\section{Employer Size and Job Creation: Empirical Findings}

We take two approaches to investigating whether small businesses create more jobs. First, following the tradition established by Birch (1987) and Davis et al. (1996a), we divide businesses into different size categories and examine whether there is a significant difference in net job creation rates across firm and establishment size categories. Second, we non-parametrically estimate the relationship between employment growth and firm or establishment size to avoid any potential biases or loss of information introduced by using arbitrary size boundaries.

\subsection{Job creation and destruction by employer size}

\subsubsection{Measurement of employer size and job creation and destruction}

It is common practice in this area to divide businesses into different size categories and then investigate the variation in net job creation across size categories (see, e.g., Birch, 1987; Davis et al., 1996a, 1996b). Following this practice, we define the size of a business in the following two ways:

\footnotetext{
${ }^{26}$ For more details, see Kolko and Neumark (2007). We minimize this problem by not using the last couple of years of data, and instead end the sample period in 2004.

${ }^{27}$ For the purposes of research on other topics, advantages of the NETS data include the capture of businesses relocation within the U.S., the ability to disaggregate to a fine geographic level, as well as ease of access and the absence of confidentiality restrictions.
} 
Base-year size: the size of the business at the starting point of the interval over which employment growth is calculated. This is the definition used by Birch $(1979,1981,1987)$, which was criticized by Davis et al. because it tends to overestimate the contribution of small businesses to job creation due to the "regression fallacy."

Average size: the simple average of business size in base year $(t-1)$ and current year $(t)$. This definition was proposed by Davis et al. to avoid the regression fallacy. ${ }^{28}$ Remember that the regression fallacy stems from the fact that some businesses are categorized as small only due to random measurement errors or transitory employment declines that influence measured employment on a year-toyear basis and thus will regress to the mean in a short time. Using this average size measure, one will treat a business as small only if it stays small for at least two years. The underlying assumption is that random measurement errors and transitory employment declines do not last two years.

It is important to note that using this average size definition one can find a less important role of small businesses in job creation than using the base-year definition even if regression to the mean does not exist. Consider an example in which every business grows with a positive rate and the measurement is always accurate. By construction, there will be no bias due to the regression fallacy in the calculation of job creation using the base-year size definition. However, the average size definition will still give a lower job creation rate among small businesses than the base-year size definition, because the fastestgrowing businesses, even if they start small, will be less likely to be categorized as small under the average size definition. Therefore, although calculations based on average size tend to mitigate the potential biases from the regression fallacy, we should not interpret the difference between calculations based on these two size definitions as solely resulting from the regression fallacy.

Our analysis focuses on firms, but is also applied to establishments. One may argue that firm size is a more relevant measure to study than establishment size. Indeed, government regulations related to small businesses usually target small firms instead of small establishments. ${ }^{29}$ However, because some

\footnotetext{
${ }^{28}$ As noted earlier, they call it "current" size.

${ }^{29}$ All federal agencies are required to use the business size standard developed by the U.S. Small Business Administration to determine eligibility for federal contracts, programs, and regulations specifically designated for
} 
previous studies were conducted at the establishment level, establishment-level analyses are useful for comparison purposes.

For businesses in each size category, we use the following measures to quantify their contributions to job creation, again following Davis et al. (1996a):

Gross job creation: the sum of employment gains over all businesses whose employment level is greater than a year ago. Businesses just started are assumed to have zero employment prior to opening, and thus this measure captures both job growth at expanding businesses and job creation by business openings.

Gross job destruction: the sum of job loss over all businesses whose employment level is smaller than a year ago. Businesses just closed are assumed to have zero employment after closing, and thus this measure captures both job decline at contracting business and job loss due to business closures.

Net job creation: the difference between gross job creation and gross job destruction. Net job creation is the most relevant measure, insofar as we care about growth in the number of jobs. However, it is interesting to look at gross job creation and destruction to learn how the net growth is achieved. For example, a 3\% net job creation rate can be a result of either a $5 \%$ gross job creation rate net of a $2 \%$ gross job destruction rate, or a $13 \%$ gross job creation rate net of a $10 \%$ gross job destruction rate. The latter case involves much more reallocation of jobs among businesses, an issue of some importance in the macroeconomic literature. ${ }^{30}$

\subsubsection{Main results}

The first two panels in Table 1 report information on job creation by firms of different sizes, using the base-year and average size definitions. The first column shows the annual average net number

small businesses. In this size standard, small business is defined either by number of employees or average annual receipts and the calculation of size "includes the employees or receipts of all affiliates." See http://www.sba.gov/services/contractingopportunities/sizestandardstopics/indexguide/index.html (viewed October 7, 2007). The U.S. Bureau of Labor Statistics (BLS) also uses firm size when it publishes statistics on employment dynamics by employer size (Butani et al., 2006).

${ }^{30}$ These gross job creation and destruction statistics calculated at the firm or establishment level still underestimate worker reallocation. For example, within an establishment some jobs (e.g., assemblers) may be destroyed and some others (e.g., technicians) may be added, with no change in overall employment. Studying worker reallocation requires the ability to track individual workers, as in the Longitudinal Employer-Household Dynamics data (http://lehd.did.census.gov/led/, viewed October 7, 2007). 
of jobs created in each size category during 1992-2004. We follow this, in the second column, by showing average annual employment in each size category. The third column reports the ratio of the two (in percentage terms), scaling average net job creation by the amount of employment in the size category. This provides one measure of the rate at which jobs are created in each size category. The fourth column reports an alternative calculation of the job creation rate, based on averaging the job creation rate from each year of the data. ${ }^{31}$ As it turns out, the figures in the third and fourth columns are very similar.

When the base-year size is used, in Panel I, we find that net job creation is high for the smallest firms, and decreases sharply with firm size. While the average annual rate of job creation in the 0-19 category is $10.9 \%$ (using the number in the third column), it falls to about $-1.1 \%$ and $0.5 \%$ for firms with between 20 and 999 workers, and is always negative - indicating net job loss - for firms with 1,000 or more workers, with rather large negative net job creation rates for large firms. ${ }^{32}$ These findings clearly suggest an important role of small firms in job creation, consistent with Birch’s (1979, 1981, and 1987) findings using the same method.

The second panel in Table 1 presents the results using the average size definition. Under this size definition, the rate of net job creation for small firms falls considerably to $2.9 \%$ (from $10.9 \%$ ). More generally, the differences in the net job creation rate by firm size become more muted. For example, using average firm size, we find none of the large negative net job creation rates for the largest firms that we found using base-year size; indeed the rate is negative for only one of the largest size categories, and in this case the estimate is smaller (in absolute value) than in Panel I. Nonetheless, overall there is still a clear negative relationship between the net job creation rate and firm size. ${ }^{33}$ The net job creation rate declines fairly monotonically with size, although there is some evidence of a higher net job creation rate for the largest firms (50,000 or more).

\footnotetext{
${ }^{31}$ That is, the third column reports the ratio of averages, and the fourth column the average of ratios.

${ }^{32}$ We refer to "workers," but the NETS also includes owners.

${ }^{33}$ Relative to the differences in the estimates under the base-year size definition, these differences in growth rates among average size categories seem small. However, since these are annual growth rates, the differences are still quite substantial.
} 
Comparing Panels I and II in Table 1, we do see evidence consistent with the regression fallacy. In particular, the base-year size definition tends to greatly overestimate net job creation by the smallest firms, and to underestimate net job creation by the largest firms. In this sense, for these data the concern of Davis et al. over Birch's methodology is well justified. However, our results in Panel II suggest that Birch's conclusion is still valid, though to a lesser extent than is suggested by his methods.

Much of the evidence in Davis et al.’s work focuses on establishments rather than firms, so in the bottom two panels of Table 1 we report similar calculations by establishment size category. The evidence on net job creation by establishment size is qualitatively similar. Using the base-year size categories, in Panel III, the net job creation rate clearly decreases with establishment size. Total jobs at establishments with 19 or fewer employees grow by $15.2 \%$ annually. Establishments in all other size categories show a negative net job creation rate. Again, the differences are muted considerably when using the average size definition (Panel IV). Under this size definition, the rate of net job creation for the smallest establishments falls sharply to $2.6 \%$ (from $15.2 \%$ ). The same rate for the largest establishments, on the other hand, becomes much higher $(-1.5 \%$, in contrast to the $-10.2 \%$ calculated using the base-year size definition). However, there is still an overall negative relationship between the net job creation rate and establishment size, with only establishments with fewer than 500 workers creating jobs, and establishments in higher size categories losing jobs.

The results in Table 1 are different from the findings in Davis et al. (1996a, 1996b). In particular, looking at establishments, Davis et al. find that once they use the average size definition instead of the base-year size definition, the important role of small businesses in job creation as emphasized by Birch (1979, 1981, and 1987) completely disappears, and there is instead either no relationship or a positive relationship between net job creation and establishment size. ${ }^{34}$ In contrast, we still find that small establishments create more jobs even if the average size definition is used, although the results are less striking. And the results are similar for firm size, which may be more relevant to the question of public

\footnotetext{
${ }^{34}$ See their Table 4.2. Just to clarify, this positive relationship emerges for their "current" size measure, which we label "average establishment size." The correlation between net job growth and the ranking of this size category is 0.75 , and the correlation between net job growth and the midpoint of the size category (using 7,500 for the 5,000 or more category) is 0.46 .
} 
policy. Therefore, these findings point to the importance of avoiding the regression fallacy in estimating the size-growth relationship. However, there still seems to be some truth to Birch's original conclusion regarding the important role of small businesses in job creation.

In Table 2, we report information on gross job creation and destruction at the firm level. ${ }^{35}$ As noted earlier, we do not observe simultaneous job creation and job destruction at the same establishment. We do not measure simultaneous job creation and destruction at different establishments belonging to the same firm. Nonetheless, the across-firm reallocation measures are of interest in light of the policy debate about the role of small firms in job creation, in which those who argue the small firms create a disproportionate share of jobs sometimes fail to point out that they also destroy a disproportionate share of jobs. $^{36}$

As reported in Table 2, when the base-year size is used, we find that the smallest firms do create a disproportionate share of jobs. ${ }^{37}$ This is perhaps most easily seen by comparing the third and fifth columns of Panel I. Firms with fewer than 20 workers create $51.1 \%$ of the total increase in employment at firms that grow, yet they account for only $26.7 \%$ of total employment. Firms in all other size categories have a gross job creation share (third column) smaller than their employment share (fifth column). On the other hand, the smallest firms account for only a slightly disproportionate share of job destruction, as shown by a comparison of the fourth and fifth columns in Panel I (28.9\% of gross job destruction, relative to a $26.7 \%$ employment share). Finally, the relationship between gross job creation or destruction and firm size is not monotonic, as the smaller firms outside of the smallest category have relatively low gross job creation and destruction rates.

Of course the same regression to the mean fallacy can drive the findings for gross job creation and destruction. Panel II, which uses the average firm size measure, leads to differences with respect to

\footnotetext{
${ }^{35}$ We treat the firm as the unit of analysis. We compute jobs created at firms that grew and jobs destroyed at firms that shrunk, and then sum these within size categories to obtain gross job creation and destruction by size category.

${ }^{36}$ See de Rugy (2005) for numerous examples. We could, in principle, compute gross creation and destruction at the establishment level and aggregate up to the firm. However, this treats single and multi-establishment firms asymmetrically, and is less closely related to the policy debate. (Moreover, this would still fail to capture withinestablishment job reallocation and would hence be difficult to interpret.)

${ }^{37}$ We report these results for firms only; the results are qualitatively similar for establishments.
} 
two findings. First, the smallest firms still generate a disproportionate share of gross job creation (35.1\%, relative to a $27.2 \%$ employment share), although the imbalance is less extreme. On the other hand, there is stronger evidence that the smallest firms also generate a disproportionate share of gross job destruction (33.9\%, relative to the $27.2 \%$ employment share). Second, the gross job creation and gross job destruction rates for the largest firms are now much more in balance than suggested by the estimates in Panel I, which helps account for the more moderate changes in net job creation rates with size that we reported in Table 1.

\subsubsection{Sensitivity and robustness analysis}

We have conducted a series of analyses to assess the sensitivity and robustness of the main results. The results of some of these analyses are reported in Table 3 and Appendix Table A1, and others are discussed in the text. In Panel I of Table 3, we report results for firms, always using the average size definition. For comparison purposes, the first column of Panel I shows the baseline net job creation rates across firm size categories (reproducing the fourth column of Panel II in Table 1).

First, we explore the sensitivity of the results to using a longer (two-year instead of one-year) interval over which to measure job creation. Measures of employment dynamics are potentially sensitive to the interval length. This is particularly true of gross flows. For example, as the interval length increases, the share of gross job creation due to births has to increase, as does the share of gross job destruction due to deaths. However, there are no necessary implications for net job creation, either overall or by firm size. The results in the second column of Panel I, which are annualized net job creation rates calculated using growth over two-year intervals, are very similar to the baseline estimates in the first column, indicating net job creation rates that are highest for the smallest firms and decline nearly monotonically with firm size, again with the exception of the largest size category.

In the third column, we revert to one-year intervals, but look at net job creation excluding births, to see whether the faster rate of job creation at small businesses is driven only by births, or also holds for existing small firms. The results are rather striking, and indicate that if we exclude births, the net job 
creation rate is slowest at the smallest firms. ${ }^{38}$ It is clearly of interest to understand the sources of the overall faster rate of job creation among smaller firms. However, the evidence that it comes from births should not be interpreted as undermining the view that small firms create more jobs, or as suggesting that policies directed at helping small firms are misplaced. With regard to the first point, the estimates simply reflect the fact that firm births tend to result, in the short-run, in small firms rather than big firms. Since small firms also die at a higher rate, if we omitted deaths we would find the opposite result. With regard to policy, there is no reason to presume that policies aimed at helping small businesses are not as responsible or more responsible for business births as for the growth of existing small businesses. Even if these policies do not directly lead to births of new businesses, any forward-looking entrepreneur would take account of the benefits made available to small firms in deciding whether to start a new company, because new firms are originally small, and most remain small.

Next, we turn to some results on establishments - the unit of analysis emphasized in Davis et al. (1996a). Given that these authors used the LRD data, which cover only the manufacturing sector, their results could be unique to manufacturing. We therefore replicated our baseline calculations for manufacturing establishments only; for comparison purposes, we also did this for services establishments. The results are shown in the second and third columns of Panel II in Table 3 (the first column reproduces the baseline establishment-level results). The results for the manufacturing sector are a bit different from the baseline results using all industries. First, manufacturing establishments in all size categories except the smallest lose jobs, which contrasts with the baseline and services sector results that only establishments with 500 or more employees lose jobs, but is consistent with the fact that manufacturing has been a declining sector. Second, compared to the baseline results and the services sector, the relationship between size and growth is not as clear for manufacturing establishments. It is true that only the smallest establishments gain jobs on net, and the largest establishments lose the most jobs. But in the intermediate categories the relationship is not monotonic. Nonetheless, the results indicate that the net

\footnotetext{
${ }^{38}$ This parallels results reported in Butani et al. (2006).
} 
job creation rate declines with establishment size in the manufacturing sector as well. ${ }^{39}$ Therefore, these findings suggest that, for the more recent sample period we study, the conclusions that Davis et al. reached do not apply to firms overall, to establishments overall, or to establishments in either the manufacturing or the services sector.

Finally, we explored a number of other measurement issues in the NETS data. As mentioned above and documented in Neumark et al. (2007), a considerable share of employment data in the NETS are not actual but imputed. The NETS database always indicates whether a particular employment number is imputed or not, making it possible to check whether our main result is robust to the use of imputed employment data. We were interested in exploring the potential consequences of this imputation for the size-growth relationship. Given that the NETS data are at the establishment level, we do this analysis for establishments, rather than firms. ${ }^{40}$ In particular, we redid the calculations dropping establishments with imputed employment data. This is carried out in four different ways: (1) dropping an establishment if its employment is imputed in every year; (2) dropping an establishment if its employment is imputed in more than 50\% of years; (3) dropping an establishment if its employment is imputed in more than $25 \%$ of years; and (4) dropping an establishment if its employment is imputed in any year.

Overall, unless the data exclusion criterion is extremely stringent, the results resemble the baseline results. ${ }^{41}$ When we drop the establishments with all, more than half, or more than one-quarter imputed employment data, the results still indicate that small establishments have higher net job creation rates and the net job creation rate declines with size. Only when establishments with any imputed data are dropped is there no longer an indication that net job creation is higher at smaller establishments; however, this last analysis uses a sample that is very restrictive, dropping $73 \%$ of the establishments. It is reassuring that the main result does not disappear even when many observations with imputed data are dropped. It is also not entirely surprising that the results are affected by the stringent criterion of

\footnotetext{
${ }^{39}$ The correlation between net job growth and the ranking of size category is -0.86 , and the correlation between net job growth and the midpoint of the size category (using 7,500 for the 5,000 or more category) is -0.87 .

${ }^{40}$ In principle, one could define employment for a given firm and a given year as imputed if data for any establishment in the firm in that year are imputed. However, in such cases the imputation may cover a very small share of the firm's employment.

${ }^{41}$ The results are reported in Appendix Table A1.
} 
dropping observations with any imputed data. Neumark et al. (2007) show that imputation is most common for early observations on new establishments, so that imposing a restriction of no imputed data might generate a non-random sample that, for example, excludes small new establishments in certain industries that tend not to be picked up right away by $\mathrm{D} \& \mathrm{~B}$.

As also documented in Neumark et al. (2007), the distribution of employment numbers in the NETS data tends to be disproportionally concentrated on multiples of 10 or 100 . We consider this a sign that some of the employment data have been rounded. Naturally, we are concerned that the higher net job creation rates of small establishments may be an artifact of rounded employment data, although there is no obvious reason why rounding would create bias in this direction. We have investigated the problem of rounded employment data in two ways. ${ }^{42}$ First, we drop the establishments that seem most likely to have rounded employment numbers. Specifically, we exclude an establishment from our calculation if its employment is a multiple of 10 or 100 in every year. The results are quite similar to the baseline, showing a monotonically decreasing rate of net job creation with establishment size. Second, instead of dropping establishments that may be reporting rounded data, we instead consider ways in which the employment data might have been rounded, and artificially round all employment data in the same way. We then recalculate net job creation rates across establishment size groups using the artificially rounded data. The idea is that if our results are affected by systematic differences in which establishments have rounded employment data, then the results from the artificially rounded data are likely to be significantly different from our baseline results. The results, however, were insensitive to this artificial rounding. ${ }^{43}$ In all cases, the results still indicated that small establishments have higher net job creation rates, and as in the baseline results, only establishments with fewer than 500 employees were net job creators while establishments in all larger groups were estimated to destroy jobs on net.

\footnotetext{
${ }^{42}$ These results are not reported in tables, but are available from the authors upon request.

${ }^{43}$ We artificially rounded the employment data in four different ways: (1) round every employment number to the nearest multiple of 10; (2) round every employment number down to the nearest multiple of 10; (3) round every employment number up to the nearest multiple of 10; and (4) round every employment number to the nearest multiple of 10 if it is under 100, and to the nearest multiple of 100 otherwise. All of these methods except the third resulted in substantially fewer observations because of small establishments that had their data rounded to zero.
} 


\subsection{Job creation and employer size: non-parametric estimation}

In the previous section, we followed existing research by dividing firms or establishments into different size categories to examine the relationship between the net job creation rate and employer size. The choice of the size boundaries - while consistent with the ones used in the existing literature - is nevertheless arbitrary. ${ }^{44}$ The particular employer size-class boundaries that are chosen could obscure the relationship between employer size and the employment growth rate. In order to check the robustness of this relationship, and to offer point estimates for the complete range of firm or establishment sizes, we estimate the employment growth rate for every size using a non-parametric locally-weighted regression. ${ }^{45}$ Since the "regression fallacy" criticism also applies to these regression analyses, we use the average establishment size instead of the base-year size as our independent variable.

Locally-weighted regressions are computationally intensive because the amount of calculations rises exponentially with the number of observations. Our large amount of data (over 150 million observations) would require performing over 150 million weighted mean calculations, each of which would use a substantial proportion of the total observations (depending on the particular bandwidth chosen). It is not feasible for us to do this. Instead, we devised a less computationally-intensive method. We first create a mean net job creation rate and an associated frequency weight for each unique value of firm or establishment size. This reduces the number of observations enormously while still maintaining the relevant information. Then, we compute the locally-weighted smoothed means using weights that are a function of the locality and frequency of each observation. ${ }^{46}$ We use a 0.1 (10\%) bandwidth kernel and frequency-adjusted tricubic weights. While this method is not computationally equivalent to the standard approach, such smoothing would otherwise be infeasible. ${ }^{47}$

\footnotetext{
${ }^{44}$ Davis et al. (1996a) note that the choice of size-class boundaries is one of the factors that influence the magnitude of the bias associated with the regression fallacy (p. 68).

${ }^{45}$ Other researchers have estimated regressions of firm growth on firm size instead of a definition of firm-size boundaries. See, for example, Chesher (1979) and Audretsch et al. (2004). Farinas and Moreno (2000) use a nonparametric approach that is similar to ours, although there are some differences in the estimation, and their model is estimated using panel data on only about 2,200 manufacturing firms in Spain over a 5-year period.

${ }^{46}$ There are other methods that could be used to reduce the number of calculations, such as evaluating the relationship at a limited number of points (arbitrary values along a grid, or simply a more limited range of values).

${ }^{47}$ This method is a slight modification of the locally-weighted scatterplot smoothing (LOWESS) method originally
} 
To visualize the nonparametric regression results, we plot the estimated mean net job creation rate against average size. Note that the number of jobs and its change are necessarily integers; the smallest unit is one. When firm or establishment size is close to zero, even a one-unit change (the smallest possible non-zero growth/decline) in total employment amounts to very large growth or decline in percentage terms. Therefore, the variance of the job growth rate is many times larger when firm or establishment size is close to zero. Although this is essentially an artifact of the data at the individual firm or establishment level, it obscures the picture of the relationship between job growth rate and size. As a result, if we plot the relationship over the whole range of firm or establishment sizes, it always appears that the change in job growth rate is very large at the smallest sizes and indiscernible beyond that. Similarly, if we extend the figure to the largest possible size, its shape is hard to discern. To show the relationship more clearly, therefore, in each figure we present results for more restricted ranges: 5 to 50,000 employees for firms, and 5 to 5,000 employees for establishments.

Figure 1 shows the results for firms, and Figure 2 for establishments. As shown in Figure 1, the net job creation rate clearly declines with firm size throughout most of the range of firm sizes except at the high end of the range (which is consistent with what was reported earlier in Table 1). ${ }^{48}$ For establishments, paralleling the analysis in Table 3, we also estimated the relationship using the manufacturing and services sectors separately. For the whole sample, Figure 2 shows that net job creation rate decreases monotonically with establishment size. The differences between the two subsamples are clear. The services sector results are almost indistinguishable from the results using the whole sample. For the manufacturing sector, the size-growth relationship is more irregular, and exhibits an increasing rate of net job creation over much of the size range up to around 400 employees. Nonetheless, net job creation declines with size. In addition, as noted earlier, the manufacturing sector shows job declines across almost the entire range of establishment size.

proposed by Cleveland (1979). This estimation procedure is described in greater detail in the earlier working paper version of this study (Neumark et al., 2008).

${ }^{48}$ In this figure we otherwise use the data the same way as in Panel II of Table 1. 


\section{Conclusions}

It has long been debated whether small businesses create more jobs than larger ones. The debate attracts a great deal of attention both in academia and in the media because it has important implications for policymaking. David Birch’s book (1987) was probably the most prominent catalyst for this debate, arguing that small businesses play a much more important role in job creation than larger businesses - a view that quickly became the conventional wisdom. Yet this work was criticized, most notably by Davis et al. (1996a), who argued that Birch’s findings are essentially a result of a flawed methodology applied to some unsuitable data.

Using newly-available data on firms and establishments for the whole U.S. economy, we revisit the issue of business size and job creation. The data are drawn from the NETS database, which was recently constructed using raw data collected by D\&B. Our evaluation of the NETS data in separate work suggests that these data are rather reliable, and a clear improvement upon early versions of the D\&B data used by David Birch in the 1970s and 1980s. We analyze these data using two methods: one based on size classes but following the methods of Davis et al. to avoid the regression fallacy that they argue plagued Birch’s work; and the other a nonparametric method that does not need to define arbitrary employer size categories.

Like Birch, we find that small firms (and small establishments as well) create more jobs. At the same time, we confirmed that the concern of Davis et al. regarding Birch's methods is well grounded, and the base-year size definition used by Birch indeed badly overestimates net job creation rates for small firms or establishments. However, when we use the methodology proposed by Davis et al. to avoid the regression fallacy, we still find that small firms and establishments create more jobs, although the difference is smaller than that originally suggested by Birch. Moreover, in more direct contrast to the results in Davis et al. (1996a), we also find that the relationship between establishment size and job creation is negative in the manufacturing sector. Thus, at least for the recent sample period we study, there appears to be a robust finding that small businesses do create more jobs. 


\section{References}

Acs, Zoltan J. and David B. Audretsch, “Editors' introduction,” Small Business Economics 1, 1989, 1-5.

Audretsch, David B., Luuk Klomp, Enrico Santarelli, and A. Roy Thurik, “Gibrat’s Law: Are the Services Different?," Review of Industrial Organization 24, 2004, 301-324.

Audretsch, David B. and Roy Thurik, "What's New about the New Economy? Sources of Growth in the Managed and Entrepreneurial Economies,” Industrial and Corporate Change 10, 2001, 267-315.

Baldwin, John and Garnett Picot, "Employment Generation by Small Producers in the Canadian Manufacturing Sector,” Small Business Economics 7, 1995, 317-331.

Barnes, Matthew and Jonathan Haskel, "Job Creation, Job Destruction and the Contribution of Small Businesses: Evidence for UK Manufacturing,” Working Paper No. 461, University of London, 2002.

Birch, David L., The Job Generation Process, unpublished report prepared by the MIT Program on Neighborhood and Regional Change for the Economic Development Administration, U.S. Department of Commerce, Washington, DC, 1979.

Birch, David L., “Who Creates Jobs?” The Public Interest 65, 1981, 3-14.

Birch, David L., Job Creation in America: How Our Smallest Companies Put the Most People to Work, Free Press, New York, 1987.

Broersma, Lourens and Pieter Gautier, “Job Creation and Job Destruction by Small Firms: An Empirical Investigation for the Dutch Manufacturing Sector,” Small Business Economics 9, 1997, 211-224.

Brown, Charles, James Hamilton, and James Medoff, Employers Large and Small, Harvard University Press, Cambridge, Massachusetts, 1990.

Butani, Shail J., Richard L. Clayton, Vinod Kapani, James R. Spletzer, David M. Talan, and George S. Werking Jr., "Business Employment Dynamics: Tabulations by Employer Size,” Monthly Labor Review 129, 2006, 3-22.

Carree, Martin and Luuk Klomp, "Small business and job creation: A comment” Small Business Economics 8, 1996, 317-322.

Chesher, Andrew, “Testing the Law of Proportionate Effect,” Journal of Industrial Economics 27, 1979, 403-411.

Cleveland, William S., "Robust Locally Weighted Regression and Smoothing Scatterplots,” Journal of the American Statistical Association 74, 1979, 829-836.

Davidsson, Per, Leif Lindmark, and Christer Olofsson, “The Extent of Overestimation of Small Firm Job Creation - An Empirical Examination of the Regression Bias,” Small Business Economics 11, 1998, 87100.

Davis, Steven J., John C. Haltiwanger, and Scott Schuh, Job Creation and Destruction, The MIT Press, Cambridge, MA, 1996a.

Davis, Steven J., John Haltiwanger, and Scott Schuh, "Small Business and Job Creation: Dissecting the Myth and Reassessing the Facts,” Small Business Economics 8, 1996b, 297-315.

de Rugy, Veronique, “Are Small Businesses The Engine of Growth,” American Enterprise Institute Working Paper No. 123, Washington, DC, 2005.

Dunne, Timothy, Mark Roberts, and Larry Samuelson, "The Growth and Failure of U.S. Manufacturing Plants,” Quarterly Journal of Economics 104, 1989, 671-698.

Evans, David S., "The Relationship between Firm Growth, Size, and Age: Estimates for 100 Manufacturing Industries,” Journal of Industrial Economics 35, 1987, 567-581.

Farinas, Jose C., and Lourdes Moreno, “Firms' Growth, Size, and Age: A Nonparametric Approach,” Review of Industrial Organization 17, 2000, 249-265. 
Gallagher, Colin C., Daly, Michael J., and Thomason, Jeremy C., "The Growth of U.K. Companies and Their Contribution to Job Generation, 1985-87.” Small Business Economics 3, 1991, 269-286.

Gibrat, Robert, Les Inégalités Économiques, Librairie du Recueil Sirey, Paris, 1931.

Hall, Bronwyn H., "The Relationship between Firm Size and Firm Growth in the US Manufacturing Sector," Journal of Industrial Economics 35, 1987, 583-606.

Hohti, Satu, "Job Flows and Job Quality by Establishment Size in the Finnish Manufacturing Sector 198094,” Small Business Economics 15, 2000, 265-281.

Kirchhoff, Bruce and Bruce Phillips, "The Effect of Firm Formation and Growth on Job Creation in the United States,” Journal of Business Venturing 3, 1988, 261-272.

Kirchhoff, Bruce A. and Patricia G. Greene, "Understanding the Theoretical and Empirical Content of Critiques of U.S. Job Creation Research,” Small Business Economics 10, 1998, 154-169.

Klepper, Steven and Elizabeth Graddy, "The Evolution of New Industries and the Determinants of Market Structure,” RAND Journal of Economics 21, 1990, 27-44.

Kolko, Jed, and David Neumark, Business Location Decisions and Employment Dynamics in California, Public Policy Institute of California, San Francisco, California, 2007.

Kolko, Jed, and David Neumark, "Changes in the Location of Employment and Ownership: Evidence from California,” Journal of Regional Science 48, 2008, 717-744.

Leonard, Jonathan S., “On the Size Distribution of Employment and Establishments,” NBER Working Paper 1951, 1986.

Leonard, Jonathan S., "In the Wrong Places at the Wrong Time: The Extent of Frictional and Structural Unemployment,” in Kevin Lang and Jonathan S. Leonard (eds.), Unemployment and the Structure of Labor Markets, Blackwell, 1987, 141-163.

Lotti, Francesca, “Firm Dynamics in Manufacturing and Services: A Broken Mirror?” Industrial and Corporate Change 16, 2007, 347-369.

Neumark, David, Brandon Wall, and Junfu Zhang, "Do Small Businesses Create More Jobs? New Evidence from the National Establishment Time Series,” NBER Working Paper No. 13818, Cambridge, Massachusetts, 2008.

Neumark, David, Junfu Zhang, and Brandon Wall, “Where the Jobs Are: Business Dynamics and Employment Growth,” Academy of Management Perspectives 20, 2006, 79-94.

Neumark, David, Junfu Zhang, and Brandon Wall, “Employment Dynamics and Business Relocation: New Evidence from the National Establishment Time Series," Research in Labor Economics 26, 2007, 39-83.

Pivetz, Timothy R., Michael A. Searson, and James R. Spletzer, "Measuring Job and Establishment Flows with BLS Longitudinal Microdata,” Monthly Labor Review, 2001, 13-20.

Sachs, Jeffrey D. and Howard J. Shatz, “Trade and Jobs in U.S. Manufacturing,” Brookings Papers on Economic Activity, 1994, 1-84.

Sutton, John, “Gibrat’s Legacy,” Journal of Economic Literature 35, 1997, 40-59.

Voulgaris, Fotini, Theodore Papadogonas, and George Agiomirgianakis, "Job Creation and Job Destruction in Greek Manufacturing,” Review of Development Economics 9, 2005, 289-301.

Wagner, Joachim, “Firm Size and Job Creation in Germany,” Small Business Economics 7, 1995, 469-474.

Wallace, Nancy E., and Donald Walls, “Agglomeration Economies and the High-Tech Computer,” Fisher Center Working Paper No. 292, University of California, Berkeley, 2004.

Walls \& Associates, “NETS: National Establishment Time-Series Database,” Oakland, California, 2003. 
TABLE 1

Job creation and destruction by firm and establishment size, 1992-2004, all industries excluding government

\begin{tabular}{|c|c|c|c|c|}
\hline Size class & $\begin{array}{l}\text { Average net } \\
\text { job creation }\end{array}$ & Average employment & $\begin{array}{l}\text { Average net job creation/ } \\
\text { average employment }\end{array}$ & $\begin{array}{l}\text { Average net job } \\
\text { creation rate }^{1}\end{array}$ \\
\hline \multicolumn{5}{|c|}{ I. Base-year firm size ${ }^{2}$} \\
\hline 0 to 19 & $4,179,048$ & $38,215,617$ & $10.9 \%$ & $11.1 \%$ \\
\hline 20 to 49 & $-159,450$ & $14,389,586$ & $-1.1 \%$ & $-1.1 \%$ \\
\hline 50 to 99 & $-96,482$ & $10,325,408$ & $-0.9 \%$ & $-0.9 \%$ \\
\hline 100 to 249 & 22,107 & $11,037,856$ & $0.2 \%$ & $0.3 \%$ \\
\hline 250 to 499 & 34,820 & $7,365,998$ & $0.5 \%$ & $0.6 \%$ \\
\hline 500 to 999 & 36,366 & $6,851,664$ & $0.5 \%$ & $0.6 \%$ \\
\hline 1,000 to 2,499 & $-58,454$ & $9,670,052$ & $-0.6 \%$ & $-0.4 \%$ \\
\hline 2,500 to 4,999 & $-160,780$ & $7,155,795$ & $-2.2 \%$ & $-2.1 \%$ \\
\hline 5,000 to 9,999 & $-191,036$ & $7,084,326$ & $-2.7 \%$ & $-2.6 \%$ \\
\hline 10,000 to 24,999 & $-341,387$ & $9,431,762$ & $-3.6 \%$ & $-3.5 \%$ \\
\hline 25,000 to 49,999 & $-301,039$ & $7,600,407$ & $-4.0 \%$ & $-3.9 \%$ \\
\hline 50,000 or more & $-299,311$ & $14,267,256$ & $-2.1 \%$ & $-2.0 \%$ \\
\hline \multicolumn{5}{|c|}{ II. Average firm size } \\
\hline 0 to 19 & $1,132,487$ & $39,304,785$ & $2.9 \%$ & $2.9 \%$ \\
\hline 20 to 49 & 308,704 & $14,480,245$ & $2.1 \%$ & $2.2 \%$ \\
\hline 50 to 99 & 178,759 & $10,287,322$ & $1.7 \%$ & $1.8 \%$ \\
\hline 100 to 249 & 212,421 & $11,084,215$ & $1.9 \%$ & $2.0 \%$ \\
\hline 250 to 499 & 149,733 & $7,428,853$ & $2.0 \%$ & $2.1 \%$ \\
\hline 500 to 999 & 133,398 & $6,974,588$ & $1.9 \%$ & $2.0 \%$ \\
\hline 1,000 to 2,499 & 171,130 & $9,750,853$ & $1.8 \%$ & $1.8 \%$ \\
\hline 2,500 to 4,999 & 87,721 & $7,220,647$ & $1.2 \%$ & $1.3 \%$ \\
\hline 5,000 to 9,999 & 101,459 & $7,111,482$ & $1.4 \%$ & $1.5 \%$ \\
\hline 10,000 to 24,999 & $-16,799$ & $9,398,609$ & $-0.2 \%$ & $-0.1 \%$ \\
\hline 25,000 to 49,999 & 35,658 & $7,455,097$ & $0.5 \%$ & $0.5 \%$ \\
\hline 50,000 or more & 169,731 & $14,231,233$ & $1.2 \%$ & $1.3 \%$ \\
\hline \multicolumn{5}{|c|}{ III. Base-year establishment size ${ }^{2}$} \\
\hline 0 to 19 & $6,829,153$ & $45,003,636$ & $15.2 \%$ & $15.4 \%$ \\
\hline 20 to 49 & $-546,477$ & $20,967,053$ & $-2.6 \%$ & $-2.6 \%$ \\
\hline 50 to 99 & $-581,445$ & $16,992,400$ & $-3.4 \%$ & $-3.4 \%$ \\
\hline 100 to 249 & $-859,541$ & $19,896,321$ & $-4.3 \%$ & $-4.2 \%$ \\
\hline 250 to 499 & $-668,198$ & $11,480,730$ & $-5.8 \%$ & $-5.7 \%$ \\
\hline 500 to 999 & $-659,923$ & $9,496,506$ & $-6.9 \%$ & $-6.8 \%$ \\
\hline 1,000 to 2,499 & $-1,018,858$ & $10,891,797$ & $-9.4 \%$ & $-9.2 \%$ \\
\hline 2,500 to 4,999 & $-441,553$ & $5,305,761$ & $-8.3 \%$ & $-8.3 \%$ \\
\hline 5,000 or more & $-490,234$ & $4,792,636$ & $-10.2 \%$ & $-10.3 \%$ \\
\hline \multicolumn{5}{|c|}{ IV. Average establishment size 3} \\
\hline 0 to 19 & $1,213,084$ & $46,461,808$ & $2.6 \%$ & $2.7 \%$ \\
\hline 20 to 49 & 309,182 & $21,185,626$ & $1.5 \%$ & $1.5 \%$ \\
\hline 50 to 99 & 179,353 & $17,054,487$ & $1.1 \%$ & $1.1 \%$ \\
\hline 100 to 249 & 120,325 & $19,843,990$ & $0.6 \%$ & $0.7 \%$ \\
\hline 250 to 499 & 12,651 & $11,446,607$ & $0.1 \%$ & $0.1 \%$ \\
\hline 500 to 999 & $-60,299$ & $9,534,934$ & $-0.6 \%$ & $-0.5 \%$ \\
\hline 1,000 to 2,499 & $-102,151$ & $10,493,875$ & $-1.0 \%$ & $-1.0 \%$ \\
\hline 2,500 to 4,999 & $-43,803$ & $5,131,225$ & $-0.9 \%$ & $-0.9 \%$ \\
\hline 5,000 or more & $-66,851$ & $4,455,035$ & $-1.5 \%$ & $-1.7 \%$ \\
\hline
\end{tabular}

${ }^{1}$ Equal to the average across years of the ratio of net job creation to total employment within a size category.

${ }^{2}$ Equal to the number of employees in the initial year of the interval over which net job creation is calculated.

${ }^{3}$ Equal to the average number of employees in the initial year and the following year of the interval over which net job creation is calculated. 
TABLE 2

Rates and shares of gross job creation and destruction by firm, 1992-2004, all industries excluding government ${ }^{1}$

\begin{tabular}{|c|c|c|c|c|c|}
\hline Size class & $\begin{array}{c}\text { Average gross } \\
\text { job creation rate }\end{array}$ & $\begin{array}{c}\text { Average gross job } \\
\text { destruction rate }\end{array}$ & $\begin{array}{l}\text { Average share of } \\
\text { gross job creation }\end{array}$ & $\begin{array}{c}\text { Average share of } \\
\text { gross job destruction }\end{array}$ & $\begin{array}{c}\text { Average } \\
\text { employment share }\end{array}$ \\
\hline \multicolumn{6}{|c|}{ I. Base-year firm size ${ }^{2}$} \\
\hline 0 to 19 & $20.3 \%$ & $9.2 \%$ & $51.1 \%$ & $28.9 \%$ & $26.7 \%$ \\
\hline 20 to 49 & $5.7 \%$ & $6.8 \%$ & $5.5 \%$ & $8.1 \%$ & $10.1 \%$ \\
\hline 50 to 99 & $6.1 \%$ & $7.0 \%$ & $4.2 \%$ & $6.0 \%$ & $7.2 \%$ \\
\hline 100 to 249 & $7.8 \%$ & $7.5 \%$ & $5.7 \%$ & $6.7 \%$ & $7.7 \%$ \\
\hline 250 to 499 & $8.7 \%$ & $8.1 \%$ & $4.2 \%$ & $4.9 \%$ & $5.1 \%$ \\
\hline 500 to 999 & $9.3 \%$ & $8.7 \%$ & $4.3 \%$ & $4.8 \%$ & $4.8 \%$ \\
\hline 1,000 to 2,499 & $9.3 \%$ & $9.7 \%$ & $6.1 \%$ & $7.5 \%$ & $6.7 \%$ \\
\hline 2,500 to 4,999 & $8.2 \%$ & $10.4 \%$ & $3.9 \%$ & $6.0 \%$ & $5.0 \%$ \\
\hline 5,000 to 9,999 & $8.1 \%$ & $10.7 \%$ & $3.8 \%$ & $6.1 \%$ & $4.9 \%$ \\
\hline 10,000 to 24,999 & $7.2 \%$ & $10.6 \%$ & $4.4 \%$ & $8.1 \%$ & $6.6 \%$ \\
\hline 25,000 to 49,999 & $5.5 \%$ & $9.4 \%$ & $2.8 \%$ & $5.7 \%$ & $5.3 \%$ \\
\hline 50,000 or more & $4.3 \%$ & $6.3 \%$ & $4.0 \%$ & $7.2 \%$ & $9.9 \%$ \\
\hline \multicolumn{6}{|c|}{ II. Average firm size ${ }^{3}$} \\
\hline 0 to 19 & $13.4 \%$ & $10.4 \%$ & $35.1 \%$ & $33.9 \%$ & $27.2 \%$ \\
\hline 20 to 49 & $8.6 \%$ & $6.5 \%$ & $8.4 \%$ & $7.8 \%$ & $10.0 \%$ \\
\hline 50 to 99 & $7.7 \%$ & $6.0 \%$ & $5.3 \%$ & $5.0 \%$ & $7.1 \%$ \\
\hline 100 to 249 & $9.2 \%$ & $7.2 \%$ & $6.7 \%$ & $6.5 \%$ & $7.7 \%$ \\
\hline 250 to 499 & $10.1 \%$ & $8.0 \%$ & $4.9 \%$ & $4.8 \%$ & $5.1 \%$ \\
\hline 500 to 999 & $11.5 \%$ & $9.5 \%$ & $5.3 \%$ & $5.3 \%$ & $4.8 \%$ \\
\hline 1,000 to 2,499 & $11.6 \%$ & $9.8 \%$ & $7.5 \%$ & $7.7 \%$ & $6.7 \%$ \\
\hline 2,500 to 4,999 & $11.5 \%$ & $10.2 \%$ & $5.5 \%$ & $5.9 \%$ & $5.0 \%$ \\
\hline 5,000 to 9,999 & $11.5 \%$ & $10.0 \%$ & $5.5 \%$ & $5.6 \%$ & $4.9 \%$ \\
\hline 10,000 to 24,999 & $10.2 \%$ & $10.4 \%$ & $6.4 \%$ & $7.9 \%$ & $6.5 \%$ \\
\hline 25,000 to 49,999 & $7.3 \%$ & $6.8 \%$ & $3.6 \%$ & $4.1 \%$ & $5.2 \%$ \\
\hline 50,000 or more & $6.2 \%$ & $5.0 \%$ & $5.9 \%$ & $5.5 \%$ & $9.8 \%$ \\
\hline
\end{tabular}

${ }^{1}$ All rates and shares are calculated in each year and then averaged over the years 1992-2004.

${ }^{2}$ Equal to the number of employees in the initial year of the interval over which net job creation is calculated.

${ }^{3}$ Equal to the average number of employees in the initial year and the following year of the interval over which net job creation is calculated. 
TABLE 3

Alternative firm-level and establishment-level analyses, net job creation rates by average firm/establishment size, 1992-2004, all industries excluding government

\begin{tabular}{lccc}
\hline I. Firms & & & \\
\hline Size class & & $\begin{array}{c}\text { Use two-year changes } \\
\text { instead of one-year } \\
\text { changes (annualized) }\end{array}$ & Omitting births $^{3}$ \\
\hline 0 to 19 & Baseline results & $2.7 \%$ & $-7.6 \%$ \\
20 to 49 & $2.9 \%$ & $2.0 \%$ & $-1.3 \%$ \\
50 to 99 & $2.2 \%$ & $1.6 \%$ & $-0.1 \%$ \\
100 to 249 & $1.8 \%$ & $1.7 \%$ & $0.1 \%$ \\
250 to 499 & $2.0 \%$ & $1.8 \%$ & $0.3 \%$ \\
500 to 999 & $2.1 \%$ & $1.6 \%$ & $-0.1 \%$ \\
1,000 to 2,499 & $2.0 \%$ & $1.5 \%$ & $0.3 \%$ \\
2,500 to 4,999 & $1.8 \%$ & $1.1 \%$ & $0.6 \%$ \\
5,000 to 9,999 & $1.3 \%$ & $1.0 \%$ & $1.1 \%$ \\
10,000 to 24,999 & $1.5 \%$ & $0.3 \%$ & $-0.2 \%$ \\
25,000 to 49,999 & $-0.1 \%$ & $0.2 \%$ & $0.5 \%$ \\
50,000 or more & $0.5 \%$ & $1.3 \%$ & $1.3 \%$ \\
\hline
\end{tabular}

No. of observations

$157,040,590$

$74,592,611$

$140,845,181$

\begin{tabular}{|c|c|c|c|}
\hline Size class $^{1}$ & Baseline results & Manufacturing sector $^{4}$ & Services sector $^{4}$ \\
\hline 0 to 19 & $2.7 \%$ & $0.6 \%$ & $3.8 \%$ \\
\hline 20 to 49 & $1.5 \%$ & $-0.6 \%$ & $2.0 \%$ \\
\hline 50 to 99 & $1.1 \%$ & $-0.9 \%$ & $1.3 \%$ \\
\hline 100 to 249 & $0.7 \%$ & $-1.0 \%$ & $0.8 \%$ \\
\hline 250 to 499 & $0.1 \%$ & $-0.6 \%$ & $0.2 \%$ \\
\hline 500 to 999 & $-0.5 \%$ & $-1.3 \%$ & $-0.3 \%$ \\
\hline 1,000 to 2,499 & $-1.0 \%$ & $-2.0 \%$ & $-0.8 \%$ \\
\hline 2,500 to 4,999 & $-0.9 \%$ & $-1.4 \%$ & $-0.8 \%$ \\
\hline 5,000 or more & $-1.7 \%$ & $-3.8 \%$ & $-0.6 \%$ \\
\hline No. of observations & $176,893,094$ & $9,526,547$ & $98,330,915$ \\
\hline \multirow{2}{*}{\multicolumn{4}{|c|}{$\begin{array}{l}1 \text { This is average employer size, defined as the average number of employees in the initial year and the following } \\
\text { year of the interval over which net job creation is calculated. } \\
{ }^{2} \text { We retain only even-numbered years, to avoid overweighting the observations that are not at the endpoints of the } \\
\text { sample period. }\end{array}$}} \\
\hline & & & \\
\hline \multirow{3}{*}{\multicolumn{4}{|c|}{$\begin{array}{l}{ }^{3} \text { The smallest size class for this column should be } 0.5 \text { to } 19 \text { employees, as we omit observations in which } \\
\text { employment is zero in the base year. (We could still, in principle, have a firm with } 1 \text { employee in the base year and } \\
0 \text { employees in the subsequent year, for an average firm size of } 0.5 \text {.) }\end{array}$}} \\
\hline & & & \\
\hline \multicolumn{3}{|c|}{$\begin{array}{l}{ }^{4} \text { We treat the } 2 \% \text { of the establishments whose NAICS code changed over time as belonging to the industry in which } \\
\text { they are classified for the most number of years. In the event that an establishment is classified in two industries for } \\
\text { an equally long period of time, the more recent of the two industries is chosen. }\end{array}$} & \\
\hline
\end{tabular}


Figure 1: Net job creation rate vs. firm size ( $10 \%$ bandwidth), firms between 5 and 50,000 employees

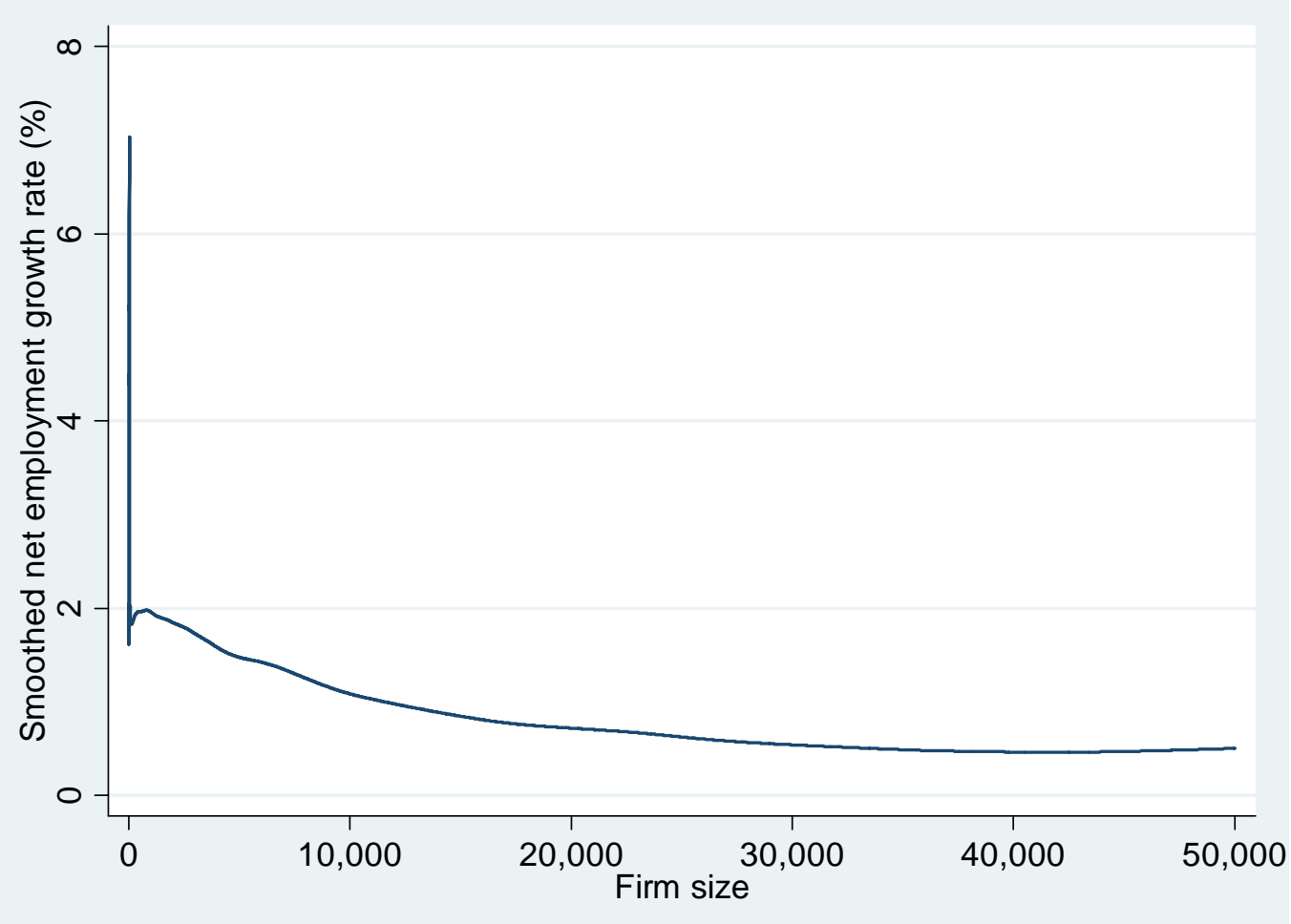

Figure 2: Net job creation rate vs. establishment size (10\% bandwidth), establishments between 5 and 5,000 employees, overall, manufacturing, and services

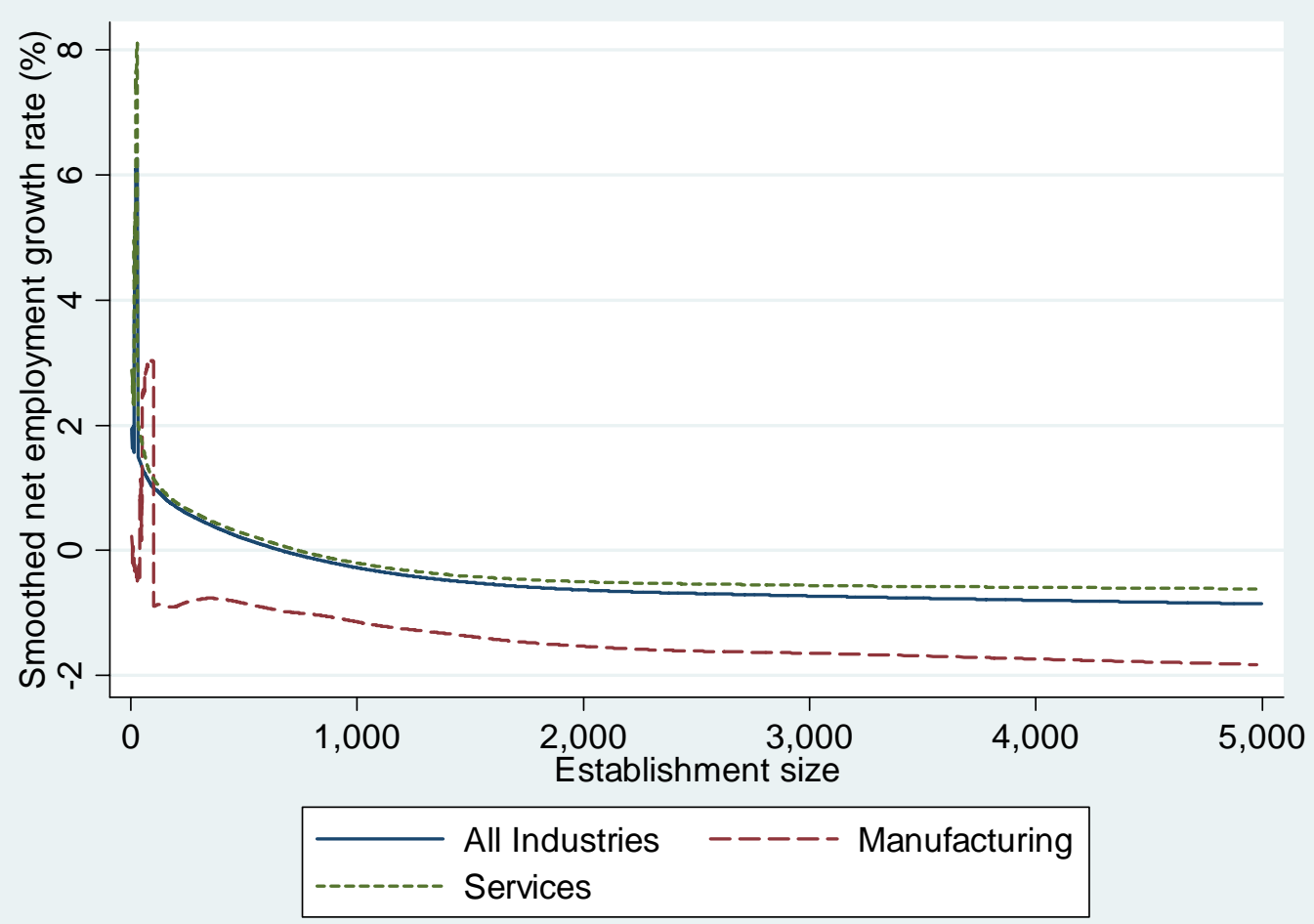


APPENDIX TABLE A1

Robustness of establishment-level results to imputation, 1992-2004, all industries excluding government

\begin{tabular}{|c|c|c|c|c|c|}
\hline Size class ${ }^{1}$ & Baseline results & $\begin{array}{c}\text { Drop any } \\
\text { establishment with } \\
\text { employment imputed } \\
\text { in every year }\end{array}$ & $\begin{array}{c}\text { Drop any establishment } \\
\text { with employment } \\
\text { imputed in more than } \\
50 \% \text { years }\end{array}$ & $\begin{array}{l}\text { Drop any establishment } \\
\text { with employment } \\
\text { imputed in more than } \\
25 \% \text { of years }\end{array}$ & $\begin{array}{c}\text { Drop any } \\
\text { establishment with } \\
\text { employment } \\
\text { imputed in any year }\end{array}$ \\
\hline 0 to 19 & $2.7 \%$ & $2.3 \%$ & $2.4 \%$ & $1.3 \%$ & $-1.8 \%$ \\
\hline 20 to 49 & $1.5 \%$ & $1.6 \%$ & $1.7 \%$ & $1.3 \%$ & $-0.1 \%$ \\
\hline 50 to 99 & $1.1 \%$ & $1.2 \%$ & $1.4 \%$ & $1.1 \%$ & $0.1 \%$ \\
\hline 100 to 249 & $0.7 \%$ & $0.7 \%$ & $0.9 \%$ & $0.7 \%$ & $-0.2 \%$ \\
\hline 250 to 499 & $0.1 \%$ & $0.2 \%$ & $0.4 \%$ & $0.1 \%$ & $-0.8 \%$ \\
\hline 500 to 999 & $-0.5 \%$ & $-0.5 \%$ & $-0.3 \%$ & $-0.7 \%$ & $-1.5 \%$ \\
\hline 1,000 to 2,499 & $-1.0 \%$ & $-1.0 \%$ & $-0.6 \%$ & $-1.0 \%$ & $-1.5 \%$ \\
\hline 2,500 to 4,999 & $-0.9 \%$ & $-1.0 \%$ & $-0.5 \%$ & $-0.7 \%$ & $-1.0 \%$ \\
\hline 5,000 or more & $-1.7 \%$ & $-1.8 \%$ & $-1.9 \%$ & $-2.2 \%$ & $-2.7 \%$ \\
\hline $\begin{array}{l}\text { No. of } \\
\text { observations }\end{array}$ & $176,893,094$ & $147,628,784$ & $119,493,862$ & $79,938,410$ & $47,322,873$ \\
\hline
\end{tabular}

${ }^{1}$ This is average establishment size, defined as the average number of employees in the initial year and the following year of the interval over which net job creation is calculated. 